\title{
溶融炭酸塩の金電極上における微小領域挙動の直接観察
}

\author{
浅野 浩一*，河瀬 誠，麦倉 良啓，渡辺 隆夫
}

(財) 電力中央研究所横須賀研究所（テ240-0196 横須賀市長坂 2-6-1）

\section{Microscopic Behavior of Molten Carbonate on Au Electrode}

\author{
Koichi ASANO,* Makoto KAWASE, Yoshihiro MUGIKURA, and Takao WATANABE \\ Central Research Institute of Electric Power Industry (2-6-1 Nagasaka, Yokosuka-shi, 240-0196, Japan)
}

Received July 12, 1999 ; Accepted January 11, 2000

\begin{abstract}
Cathode polarization is a major factor of voltage loss in molten carbonate fuel cells (MCFCs), and it is caused by oxygen reduction at the cathode. In order to clarify the interaction between the molten carbonate and the cathode in MCFCs, we have attempted to develop the in situ micro observation using an environmental scanning electron microscope (E-SEM). We could directly observe the microscopic behavior of the molten carbonate on Au electrode together with the electrochemical measurement. In secondary electron images, we found that there is the thin film of molten carbonate on the electrode partially among the thick film. The thin film area on the electrode drastically changed with potential during the cyclic voltammetry. The thickness of the thin film was about $0.1 \mu \mathrm{m}$ when the potential is negative to reference electrode. We suggested that the thin film might have strong relations to active area of the cathode reaction.
\end{abstract}

Key Words : MCFC, Molten Carbonate, Micro Behavior, In situ Observation

\section{1 緒 言}

溶融炭酸塩型燃料電池 (Molten Carbonate Fuel Cell, 以下 MCFC と略記) の実用化のためには，低コスト化が重 要であり，性能面から見れば初期電圧のさらなる高電圧化が 必要である。また，寿命面から見ると，MCFCの主たる性 能劣化要因はカソード反応抵抗の増加であり, これを低減し, 電池電圧を長期に渡って安定させることが重要となっている。

MCFC の電極では，多孔質構造（細孔構造）の電極材に 電解質（溶融炭酸塩）がしみ込んでいるため, 電極反応は, 電極細孔内にできる電極（固相）|電解質（液相）|供給ガス （気相）の三相界面近傍において，反応種の気相加ら夜相へ の溶解 $\rightarrow$ 電極表面への拡散 $\rightarrow$ 電極反応 $\rightarrow$ 生成種の脱離といっ た素過程を経て進行する. カソードでは, 酸素の還元反応が 起こっており，電極細孔内における電解質分布および挙動は, 三相界面の形成，ひいてはカソード反応に大きく影響を及ほ すと考えられている.

電解質分布に関しては，電極内の細孔を単純円筒管の集合 と仮定し，各々の円筒管内部の電解質占有状態を考慮した 様々なモデルが提案されている1,2). 近年, Selman ら ${ }^{3 /}$ は, フィルムアグロメレートモデルを適用し, 電極細孔内はサブ ミクロンオーダーの電解質の薄液膜で覆われているとした。 また, Iacovangelo ら ${ }^{4)}$ ( を比較し，電解質が主にサブミクロン〜ミクロンオーダーの 細孔中に凝集していることを示した。

電解質挙動に関しては, 電解質溶液内に完全に浸漬したセ ルや，一部浸漬したセルに形成される液膜部について研究が 行われている，一般に金属が溶融塩に濡れた場合，金属表面
には液体の薄い膜（メニスカス）が形成される（Fig.1）。麦 倉ら ${ }^{5)}$ は，電池作動条件において電極と電解質が形成するメ ニスカスを直接観察し，メニスカスの高さが電位に依存する ことから, カソードで生ずる酸素の還元反応は, 浸漬部より むしろメニスカスで進行することを示した。

しかしながら，上記は何れも実電池作動条件における電極 細孔内での電解質分布および挙動を十分には説明できていな い.これは，MCFC の電池作動温度が約 $650^{\circ} \mathrm{C}$ と高温であ り，かつ予想される電解質液膜が非常に薄いため，これまで 直接観察する方法がなかったためである.

本報では，MCFCの作動温度域において電解質（溶融炭 酸塩）挙動を直接観察するための新しい方法を考案し，その 直接可視化技術の検証および微小領域における炭酸塩挙動に ついて検討した。



Fig. 1 Schematic diagram of meniscus and supermeniscus. 


\section{1 電解質挙動の直接観察装置}

\section{2 実 験}

使用した実験装置の構成概要を Fig. 2 に示す。本研究では， 環境制御型電子影 微 鏡 ${ }^{6)}$ (Nikon 社 製 environmental SEM-2700：以下 E-SEM と略記）を初めて溶融炭酸塩の観 察に用いた. E-SEM は, 検出器に数 $100 \mathrm{~V}$ のバイアスがか けられており，1次電子の入射により試料表面に発生した 2 次電子は，電界によって引き寄せられ加速される. 多少加速 された電子は直ちに，ガス分子と衝突しガス分子をイオン化 させ, 電子を余分に飛び出させる. 電子は再び加速され, ガ ス分子に衝突しイオン化する.この増幅が電界によりカスケ ード状に行われながら最後に検出器に集められ，2次電子信 号として検出される. E-SEM では, 雲囲気がスそのものが 1 つの検出増幅系として作用するため, 通常の SEM とは検 出法が異なる.このため, 試料室内部の圧力および雲囲気が ス組成を変化させても問題なく観察できる特徴がある.ま た, 2 次電子の増幅過程で発生した正イオンは, 電子とは逆 の方向へ加速され，非導電性試料に発生したチャージアップ を中性化しイオンから分子へと戻る，従って，E-SEMは， 高加速電圧下で, 非導電性試料を未処理のままチャージフリ 一の状態で試料表面を観察できる電子顕微鏡である。このよ うな E-SEM の特徵を活かし, 炭酸塩を溶融した状態で観察 するために，E-SEM チャンバー内には加熱ステージを設け た.さらに電位をかけた場合の溶融塩挙動も同時に観察する ため，E-SEM 外部に付属する電気化学測定装置から，リー ド線をチャンバー内に取り込んだ。

\section{2 試料セル}

炭酸塩を溶解するための加熱ステージは，電気炬をアルミ ナセラミック容器で覆った構造とし, 試料セルの入った金る つぼをその上に置き加熱した．Fig. 3 に試料セルの略図を示 す.試料セルには, 以下に示す電気化学測定用の作用極, 対 極および電位測定極を設けた，また，電極やリード線は，す べて炭酸塩中で安定な金を用いた。

(1) 作用極

作用極は, $2 \mathrm{~mm}$ 角, 200 mesh $(\phi 0.07 \mathrm{~mm})$ の金六 ット(ニラコ製) に金リード $(\phi 0.2 \mathrm{~mm})$ を取り付け 使用した．電極は，炭酸塩を含浸させた多孔質 $\mathrm{LiAlO}_{2}$ 上（以後, 電解質板と略記）に置きセラミックス板に て押さえつけた。

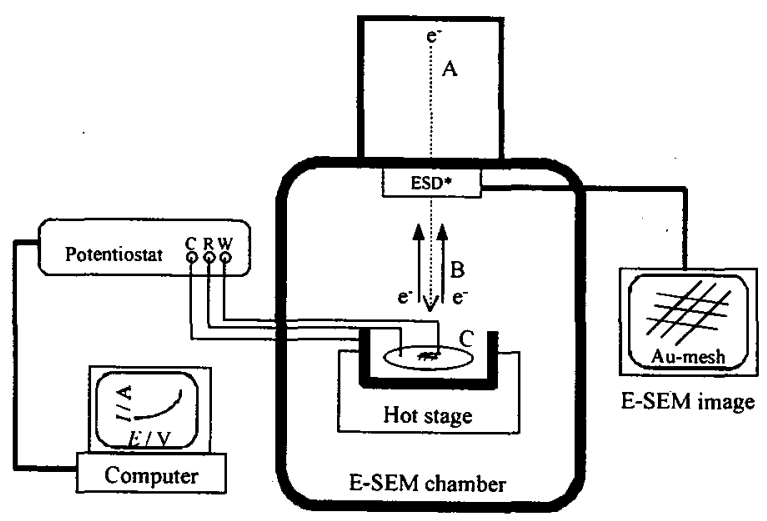

* ESD : Environmental Secondary electron Detector

Fig. 2 Experimental apparatus of in situ micro observation. $\mathrm{A}=$ primary electron, $\mathrm{B}=$ secondary electron, $\mathrm{C}=$ experimental cell (ref. $=$ Fig. 3 ).

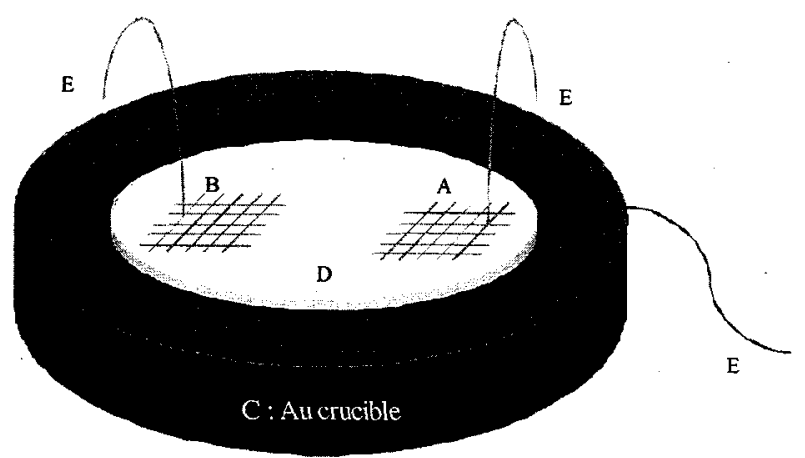

Fig. 3 Cell configuration. $A=$ working electrode, $B=$ reference electrode, $\mathrm{C}=$ counter electrode (Au crucible), $\mathrm{D}=$ electrolyte plate, $\mathrm{E}=\mathrm{Au}$ lead wire.

(2) 対極

対極は，電解質板を設置した金るつぼ全体とした（内 径 $\phi 7 \mathrm{~mm}$, 高さ $1 \mathrm{~mm}$ ).

(3) 電位測定極

現在のところ E-SEM チャンバー内には技術的に 2 種類 のガス（作用極用，基準電位電極用）を個別に供給で きないため，基準電位電極をセル内に組み込むことは できなかった．ただし，作用極一対極間に流れる電流 の影響を受けない電位測定極を用意した．電極材は， 金リード付きの $2 \mathrm{~mm}$ 角， $200 \mathrm{mesh}$ の金ネットを使用 した。また，チャンバー内のガス分圧変動をなるべく 受けないよう電解質板にて電極を挟み，その上からセ ラミックス板にて電極が動かないように固定した。

(4) 炭酸塩

電解質は, $\mathrm{Li}_{2} \mathrm{CO}_{3}$ と $\mathrm{K}_{2} \mathrm{CO}_{3}$ をル比で $62: 38$ に混合 した炭酸塩（約 $3 \mathrm{mg}$ ）を使用した。これを $\phi 5 \mathrm{~mm}$, 厚さ $0.5 \mathrm{~mm}$ の電解質板にあらかじめ含浸させた.

\section{3 電気化学測定装置}

本研究では, Solartron 社製ポテンショ/ガルバノスタット 1287 を使用し，ポテンショスタット機能を用いた. 測定は, E-SEM チャンバー内から作用極，対極および電位測定極そ れぞれのリード線をSolartron 1287 に接続し，作用極一対 極間の電位，電流值を 3 端子法にて測定した．電気化学測定 と同時に E-SEM を用いて電極表面を観察することにより， 電極反応を伴う溶融炭酸塩の微小領域挙動を観察した.

\section{4 実験前処理}

金ネット電極は，実験前，炭酸塩によって濡れていないた め, 前処理として, 試料セルを $550 \sim 600^{\circ} \mathrm{C}$ に加熱し, 炭酸 塩を溶融した状態で，電圧を作用極一対極間に数回繰り返し 印加する操作を行った.

\section{3 結果及び考察}

\section{1 E-SEM 2 次電子像における溶融炭酸塩の識別}

実験前処理中，炭酸塩は，550〜 $600^{\circ} \mathrm{C}$ の間にすべて溶融 することを確認した. Fig.4（a）（b）は，前処理を施した 後, E-SEM によって電解質板上のネット電極を構成する金 細線 $(\phi 0.07 \mathrm{~mm})$ 表面を観察した 2 次電子（Secondary Electron：S.E.) 像である。炭酸塩は，650，200 Pa（純 炭酸ガス）中において溶融し，そのS.E.像は，暗く描写さ れた. $\mathrm{Au}$ 電極の S.E. 像は，反対に明るく描写されたため， 


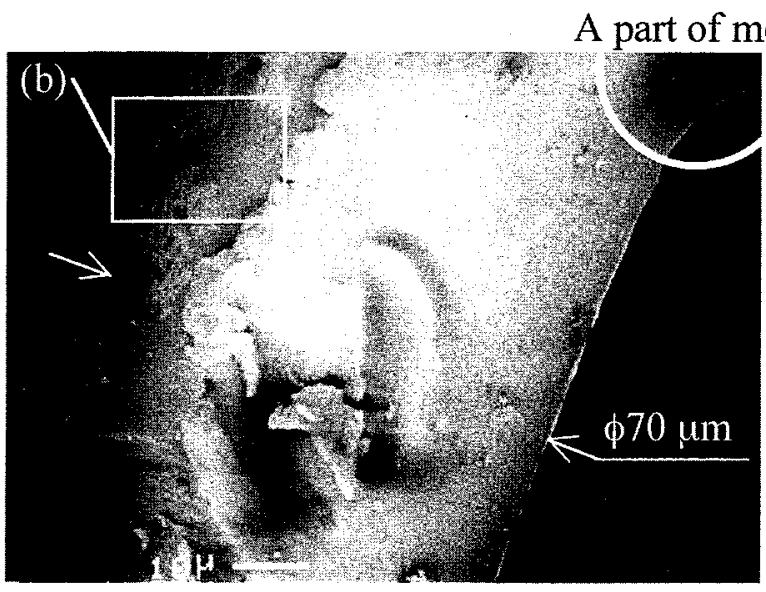

(a) $0 \mathrm{~V}$, low magnification image



(b) $0 \mathrm{~V}$, high magnification image

A part of meniscus

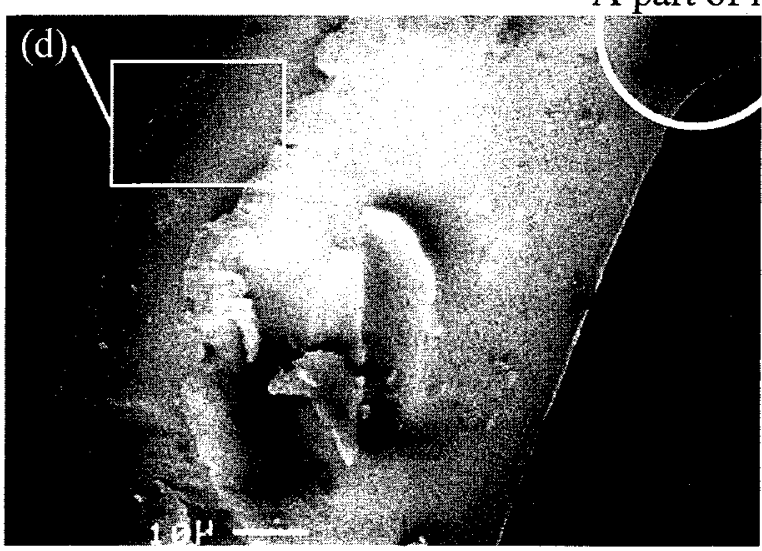

(c) $-0.8 \mathrm{~V}$, low magnification image

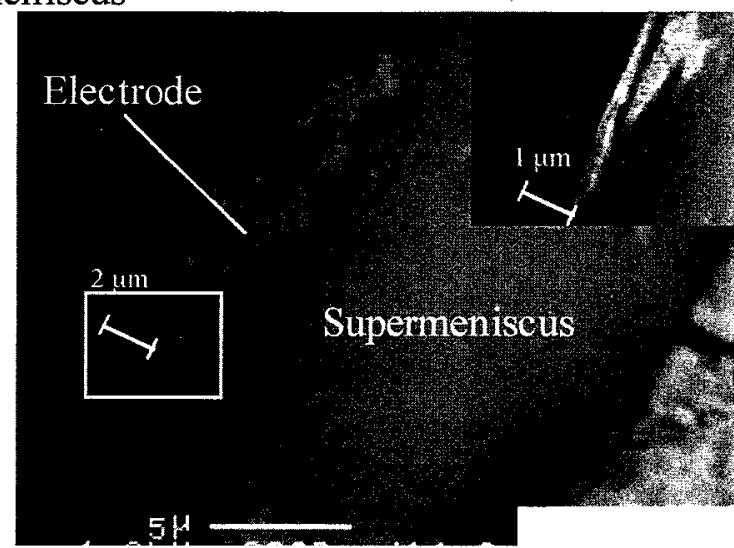

(d) $-0.8 \mathrm{~V}$, high magnification image

Fig. 4 Secondary electron (S. E.) images of molten carbonate on a part of Au-mesh electrode at $923 \mathrm{~K}$ using conditions of 200 $\mathrm{Pa}$ of pure $\mathrm{CO}_{2}, 25 \mathrm{keV}$ primary beam energy, and $13 \mathrm{~mm}$ working distance.

炭酸塩と電極の見分けを容易に行うことができた.

電極表面は，低倍率（Fig.4（a)）において炭酸䘏が溶融 した状態で電極表面に濡れているところが観察された。これ を高倍率にして観察すると, 約 $2 \mu \mathrm{m}$ までの膜厚をもつ溶融 塩薄液膜が水滴の様に大小の島状に分布していることがわか った。 その観察結果を Fig. 4. (b) に示す. 溶融塩薄液膜の 膜厚は, Fig. 5 の膜厚测定の模式図に示すようにS.E. 像に 写る $\phi 70 \mu \mathrm{m} の$ 金細線の直径方向両端部に観察される溶融 塩膜厚さ $(a \mu \mathrm{m})$ とした. Fig.1のように金属が溶融炭酸 塩に濡れた場合，金属表面にはメニスカスよりさらに薄いサ ブミクロンオーダーの薄液膜（スーパーメニスカス）の存在 が示唆されている ${ }^{3)}$.スーパーメニスカスは，今まで直接観 察されたことはないが，上記電解質薄液膜は，その膜厚オー ダーからスーパーメニスカスに相当すると考えられ, 本研究 において初めてその存在を直接観察することに成功した。

さらに，Fig.4（a）の右上角（○印部）および後で示す Fig.9（a）には，Fig.1におけるメニスカスが観察されてい る. 以上より, 本観察法によってメニスカスからスーパーメ ニスカスまでを直接観察できることがわかった，また，写真 では識別できないが, 電解質表面を観察すると, 常に電解質 が激しく動いており，ゆっくりとだが不規則に電解質薄膜の 形状が変わることを確認した。これは，炭酸塩が熱振動によ り，電極表面を絶えず流動していることを示唆している.

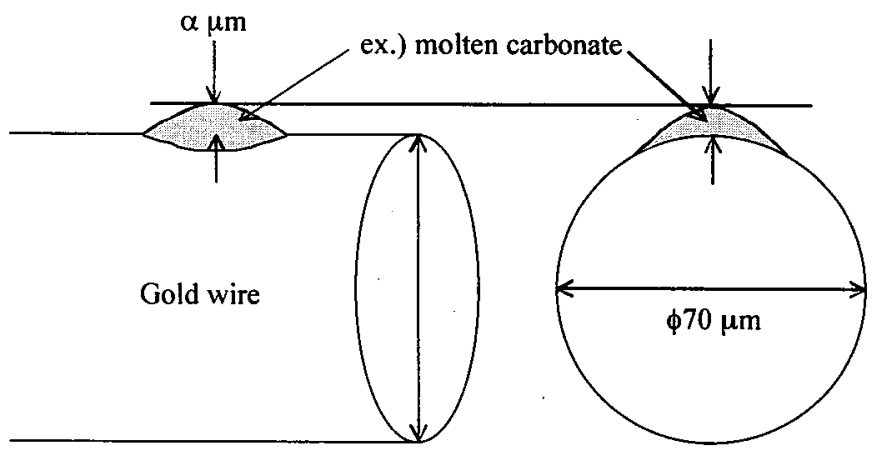

Fig. 5 Schematic diagram of the measured thickness of meniscus or supermeniscus.

\section{2 微小領域における溶融炭酸塩挙動}

サイクリックボルタンメトリー測定に伴う溶融炭酸塩挙動 をE-SEMによって観察した. Fig.6は，炭酸ガス雲囲気下 $\left(200 \mathrm{~Pa}, 650^{\circ} \mathrm{C}\right)$ におけるサイクリックボルタンモグラム (CV) を示す. 実験前処理において電圧印加回数を増やして いくと, 例えばー $0.8 \mathrm{~V}$ 付近の電流值は, 回数を増やすごと に増大した（Fig.6 (a) $\rightarrow(\mathrm{c}))$.これは，溶融した炭酸塩が 徐々に電極に馿染んだと考えられる. 本報では,この前処理 により，-0.8 V印加時の電流值がほぼ安定する 5 回目を実 


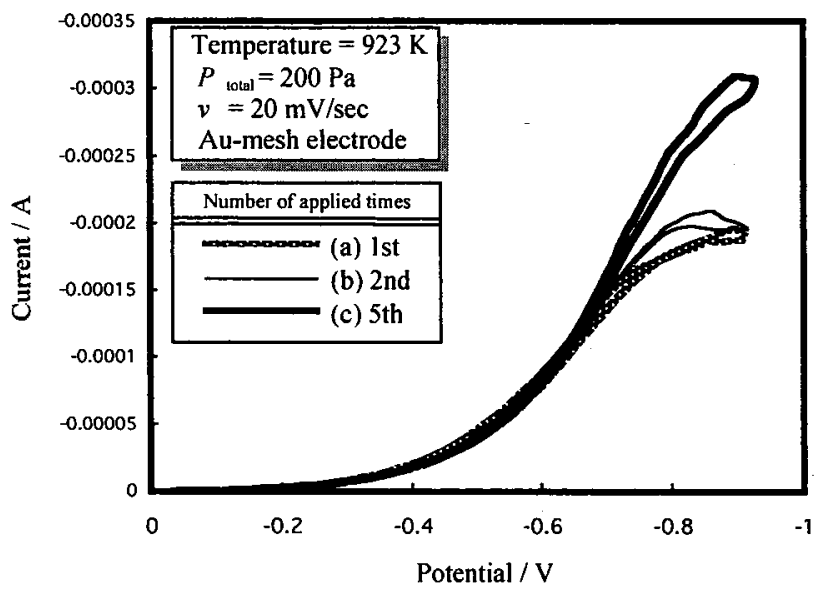

Fig. 6 Cyclic voltammograms at Au-mesh electrode in pure $\mathrm{CO}_{2}$ atmosphere.

験開始点とした.

Fig. 4 (c) (d) は， -0.8 V を印加した際の S.E.像を示す . CV 測定開始後，0 V 状態 (Fig.4（a)）で観察された炭酸塩 溥液膜は, $-0.4 \mathrm{~V} よ り$ 卑な電位において, 薄液膜に覆われ ていない電極表面を覆うように徐々に動き始めた。その後, $-0.8 \mathrm{~V}$ 付近では, 薄液膜は電極表面を覆った. $-0.8 \mathrm{~V} に$ おけるS.E.像を Fig.4（c：低倍率）に示す．この薄液膜の

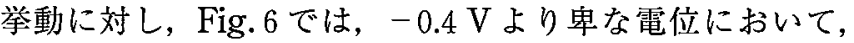
電流値が急激に増大した. その後, 電位を貴な方向に戻して いくと炭酸塩の分布状態（Fig.4（a）とあまり差異がないた め図は省略した）および電流ともに初期の $0 \mathrm{~V}$ 状態（Fig. 4 (a)）に戻った。これにより，薄液膜の挙動は電位依存性を 示し, 薄液膜の面積が電流の增大に何らか寄与していること がわかった.

そこで，高倍率における膜の挙動を観察した。 - $0.4 \mathrm{~V}$ 付 近から卑な電位になるに従い膜厚約 $2 \mu \mathrm{m}$ 以下の薄液膜は, その面積を増大させながら約 $0.1 \mu \mathrm{m}$ の膜厚に収束する傾向 を示した. その代表的な S.E.像を Fig.4（d：高倍率）に示 す.一方，Fig.4（a）○印で観察された膜厚 $2 \mu \mathrm{m}$ 以上の薄 液膜の膜厚は, 膜厚約 $0.1 \mu \mathrm{m}$ の薄液膜の面積変化ほど顕著

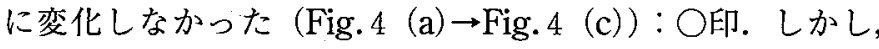
約 $2 \mu \mathrm{m}$ 以上の薄液膜であっても, その縁にかけて膜厚は薄 くなっており，膜厚約 $0.1 \mu \mathrm{m}$ の薄液膜の增大に合わせて， その面積は見かけ上わずかに増大した。

この膜厚約 $2 \mu \mathrm{m}$ より厚い薄茌膜は, 先述の光学式カメラ で観察されたメニスカス高さの電位依存性に相当すると考え られる ${ }^{5)}$. 観察されたメニスカス高さの増大は，電流の増大 に依存しており，メニスカス部で電極反応が起こっていると 考えられている.しかし，本観察の結果から，メニスカス高 さの増大は, 光学式カメラでは視認できなかった微視的領域 におけるスーパーメニスカスの面積の増大に引きずられた， または一部スーパーメニスカスを含んだ測定をした結果と考 えられる。

ここで, 本報では, 便宜上, 電位に依存して動く膜厚 $2 \mu \mathrm{m}$ 未満の薄液膜をスーパーメニスカスとし, $2 \mu \mathrm{m}$ 以上 の液膜・薄液膜をメニスカスとした。だだ，上記スーパー メニスカスの膜厚の值は，一般的に定義されたものではない． 実際にメニスカスとスーパーメニスカスとの境界はなく連続
になっているので，区別ができない。

以上より, Fig. 6 における $-0.4 \mathrm{~V} よ り$ 单な電位での急激 な電流值の立ち上がりは, 膜厚 $0.1 \mu \mathrm{m}$ 程度のスーパーメ二 スカスの面積が増大したためと考えられ，一定の膜厚を持つ スーパーメニスカスが電極反応に有効な活性場（三相界面） を含んでいることが示唆された。 また，従来，酸素の炭酸塩 への溶解度が低いため，酸素還元反応場は，サブミクロンオ ーダーのスーパーメニスカスに覆われた電極表面であると考 えられてきた ${ }^{3)}$ 。本観察結果は，これを支持する結果となっ た.

\section{3 炭酸塩薄液膜挙動}

3. 3.1 雾囲気ガス依存性 $\quad \mathrm{CV}$ 測定中, 酸素の有無に よる膜挙動変化を観察した. Fig. 7 は, $650^{\circ} \mathrm{C}$, 全圧 $200 \mathrm{~Pa}$ におけるCVである. Fig. 8 (a)〜 (d) は, Fig.7の酸素の 存在する Gas II $\left(\mathrm{O}_{2} / \mathrm{CO}_{2} / \mathrm{N}_{2}=15 / 30 / 55\right)$ 条件下に打ける CV 測定に対応した連続する S.E.像を示す.スーパーメニ スカスの挙動は, Fig. 4 の Gas I $\left(\mathrm{CO}_{2} 100 \%\right)$ 条件下 (Fig. 7 における $\mathrm{CO}_{2} 100 \%$ の条件下での CVに対応) と比 較すると, Gas II の方がスーパーメニスカスの動き始める 電位が貴であり，スーパーメニスカスが電極を覆う動きも早 くなった．酸素が存在する方が炭酸塩の動きが早くなったこ とは，炭酸塩が電極に濡れ易くなったことを意味し，炭酸塩 が卑な電位において，酸素が存在しない状態よりも接触角が 小さくなることに一致する7).また，Fig.7では，酸素が存 在するため酸素還元電流が生じたことを示している.この理 由として, (1)酸素の存在により, 反応速度が増大したこと, (2)炭酸塩がより早く電極を覆うことにより，同電位における 反応面積がより広くなったことが考えられる.

3. 3. 2 炭酸塩量依存性保手動の炭 酸塩量依存性について検討した。炭酸塩量は, 電解質板への 炭酸塩の初期含浸量を通常の 2 倍, 約 $6 \mathrm{mg}$ に調製した炭酸 塩量（A）と通常量に調整した炭酸塩量（B）（約 $3 \mathrm{mg}$ ）を 用いた. 炭酸塩量 (A) のS.E.像を Fig.9に示す. Fig.9 (a) では，炭酸塩が初期状態においてかなり電極を覆ってお り，部分的にメニスカスの大きな塊が観察された。

実際にー0.8 V の電压を印加した際, 炭酸塩量 (B) (Fig. 4 (d)）では, 炭酸塩薄液膜の拡がり方は遅く, 膜として電極 表面を覆いきれていないが，炭酸塩量（A）（Fig.9（b)）で は, 電極表面に沿って手前側のほうが，放出される 2 次電子

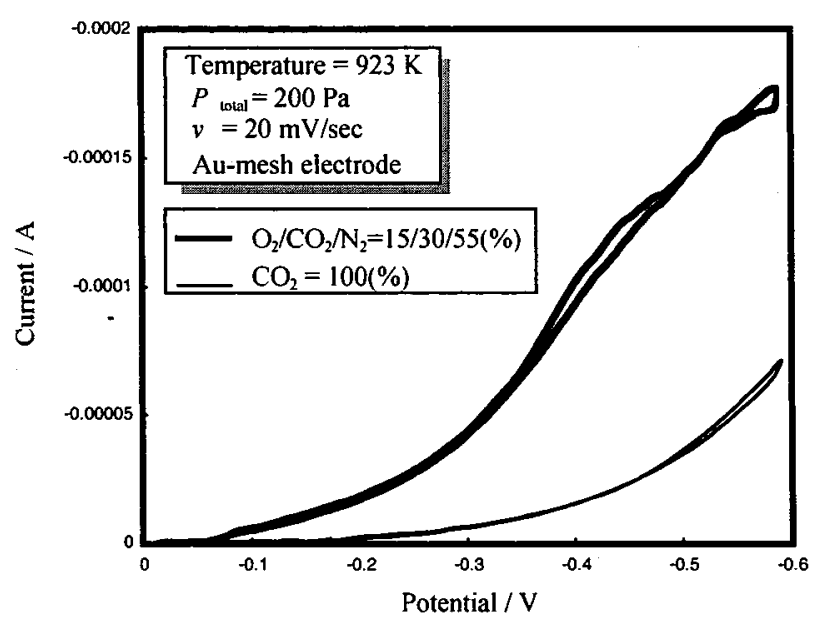

Fig. 7 Cyclic voltammograms at Au-mesh electrode in various atmospheres. 

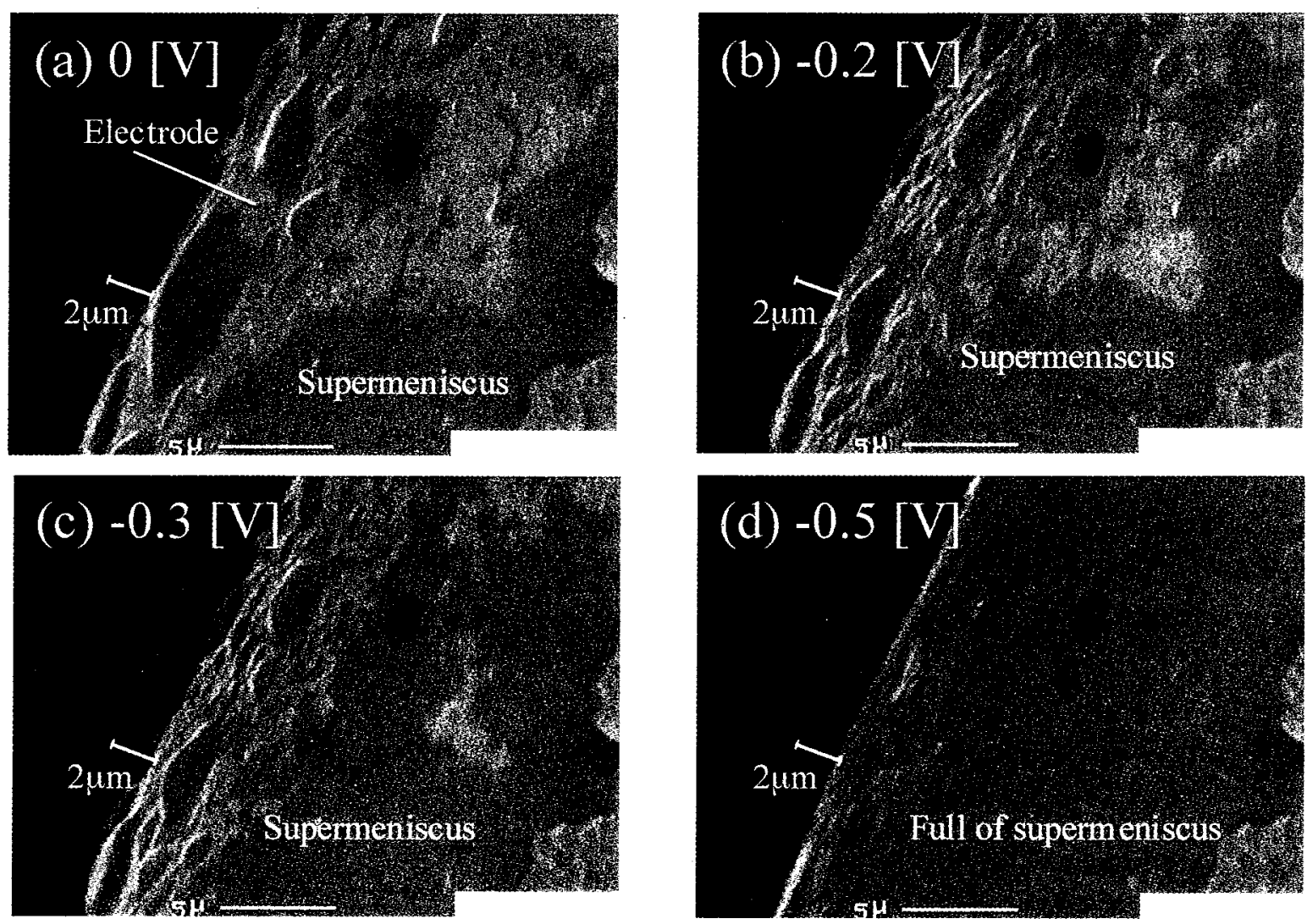

Fig. 8 S. E. images of molten carbonate on a part of Au-mesh electrode at $923 \mathrm{~K} \mathrm{using}$ conditions of $200 \mathrm{~Pa}$ of high $P\left(\mathrm{O}_{2}\right)$ gas $\left(\mathrm{O}_{2} / \mathrm{CO}_{2} / \mathrm{N}_{2}=15 / 30 / 55 \%\right), 25 \mathrm{keV}$ primary beam energy, and $13 \mathrm{~mm}$ working distance.

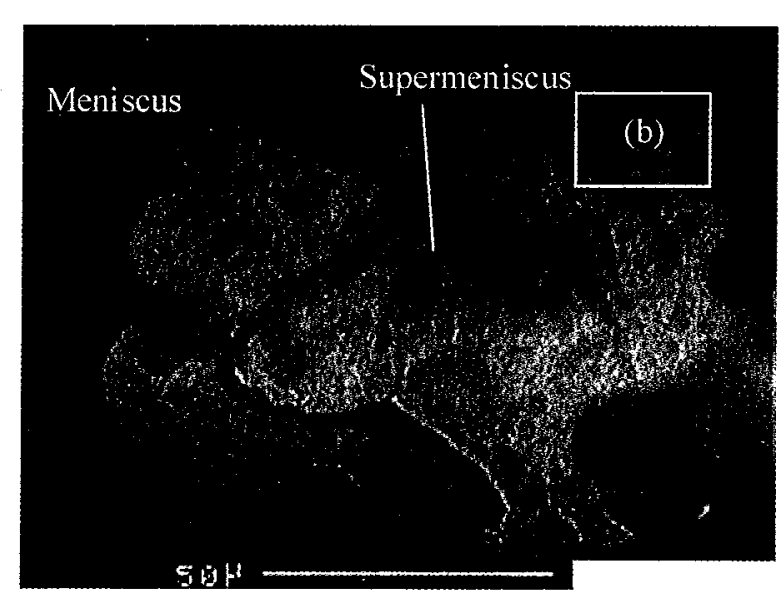

(a) $-0 \mathrm{~V}$, low magnification image

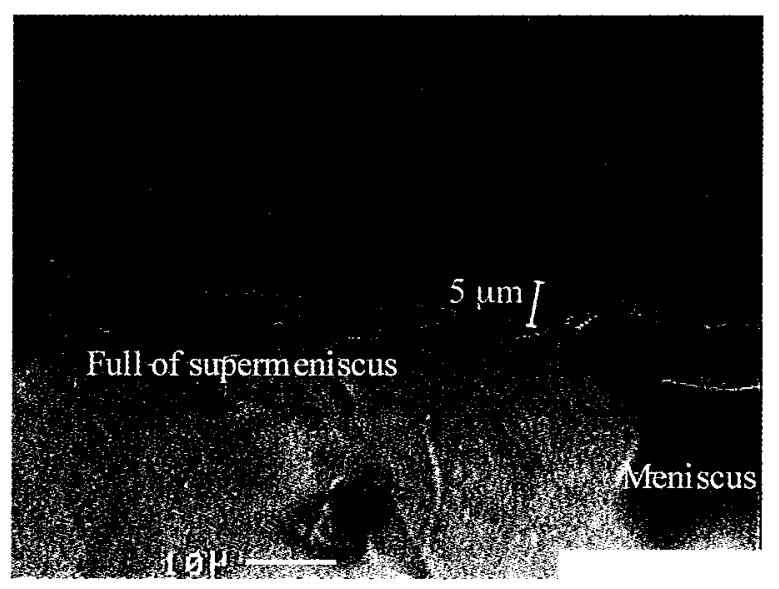

(b) $-0.8 \mathrm{~V}$, high magnification image

Fig. 9 S.E. images of large amount of molten carbonate on a part of Au-mesh electrode at $923 \mathrm{~K}$ using conditions of $200 \mathrm{~Pa}$ of pure $\mathrm{CO}_{2}, 25 \mathrm{keV}$ primary beam energy, and $13 \mathrm{~mm}$ working distance.

量が多く，少し明るくなって見にくいが，炭酸塩が電極表面 を覆い尽くしていた. Fig. 10 は，炭酸程量 (A) (B) にお ける CVを示す。炭酸塩量 (A) の場合, 電位は, $-0.8 \mathrm{~V}$ 近辺で屈曲し，それ以上電流は流れなくなった（Fig.10 (b))。一方，炭酸塩量が少ない場合，この屈曲は現れなかっ た (Fig.10 (a)).

炭酸塩量 (A) の場合, 初期の炭酸塩に覆われていない電 極表面が少ないことに加え，スーパーメニスカスは， -0.8 $\mathrm{V}$ 以上で電極表面を覆い尽くしているため，電極反応に有効
な液膜面積を増やすことができなくなる。このため，実質反 応面積の増大が不能となり，電流値の增大は横這いとなる. そして，更に供給過多となった炭酸塩によって膜は厚くなり， 徐々に有効な反応面積を失ったと考えられる，上記の結果か ら，良好な電極特性を得るための最適な電解質量の存在が示 唆される．実際の MCFCの電極特性に関しても最適な電解 質量が存在し，上記の考察と一致する。 




Fig. 10 Cyclic voltammograms at Au-mesh electrode in pure $\mathrm{CO}_{2}$ atmosphere: the effect of amount of molten carbonate (MC).

\section{4 結 論}

本報では，電気化学測定装置を付属した環境制御型電子顕 微鏡（E-SEM）を用いて，MCFCの作動温度域において溶 融炭酸塩挙動を直接観察するための新しい方法を考案し，そ の直接可視化技術の検証および微小領域における炭酸塩挙動 について検討した. その結果，以下が明らかとなった。

(1)本観察手法によって金電極表面に溶融した炭酸塩を直接観 察できたと同時に，溶融炭酸塩が，金電極表面においてメ ニスカス状態だけでなく, 従来存在が示唆されてきたサブ ミクロンオーダーの薄液膜（スーパーメニスカス）の状態 でも存在することを初めて直接観察した。

(2)サイクリックボルタンメトリー测定に伴う溶融炭酸塩挙動 を E-SEMによって観察した結果，- $-0.4 \mathrm{~V}$ 付近から卑な 電位になるに従い膜厚約 $2 \mu \mathrm{m}$ より薄い薄液膜は, その面 積を増大させながら厚膜 $0.1 \mu \mathrm{m}$ のスーパーメニスカスに
収束する傾向を示した。同時に， $-0.4 \mathrm{~V}$ より卑な電位で の急激な電流值の増大が観察された。この電流值の増大は, 上記スーパーメニスカスの面積が増大したためと考えられ， このスーパーメニスカスは電極反応に有効な活性場（三相 界面）を含んでいることが示唆された。

(3) CV 測定中，酸素の有無による膜挙動変化を観察した結果， 酸素が存在する方が炭酸塩の動きが早くなった。このこと は，炭酸塩が電極に濡れ易くなったことを意味し，炭酸塩 が 0 Vより卑な電位において, 酸素が存在しない状態よ りも接触角が小さくなることに一致した.

(4)スーパーメニスカス挙動の炭酸塩量依存性について検討し た結果，良好な電極特性を得るための最適な電解質量の存 在が示唆された.

(5)以上，本観察手法を適用することによって，溶融炭酸塩の 微小領域挙動の直接観察が可能であることがわかった. 今 後の観察・測定法の改良によって，微小領域における溶融 炭酸塩の物性把握がさらに可能になるものと思われる。

\section{文 献}

1) B. D. Cahan and J. O'M. Bocris, J. Chem. Phys., 50, 1308 (1980).

2) C. Y. Yuh and J. R. Selman, J. Electrochem. Soc., 131, 2062 (1984).

3) C. Y. Yuh and J. R. Selman, J. Electrochem. Soc., 139, 1373 (1992).

4) C. D. Iacovangelo and E. C. Jerabec, J. Electrochem. Soc., 133, 280 (1986).

5) Y. Mugikura and J. R. Selman, Denki Kagaku (presently Electrochemistry), 64, 491 (1996).

6) G. D. Danilatos, Adv. Electr. Electron Phys., 71, 109 (1988).

7) Y. Mugikura and J. R. Selman, J. Electrochem. Soc., 143, 2442 (1996). 